\title{
Effects of Imidacloprid on Histology and mRNA Levels of HSP70 and CYP1A Gene to a Standard Non-targeted Test Animal, Cyprinus carpio
}

Hemanta Pokhrel, Raktim Sarmah, Sarada Kanta Bhagabati, Rajdeep Dutta, Abdul Malik Ahmed, Dipanka Nath, Lawonu Mudoi, Lucy Ingtipi, Arnab Narayan Patowary, Binod Kalita

10.18805/IJAR.B-4706

\begin{abstract}
Background: Imidacloprid (IMI) belongs to the class of neuro active insecticides, used to control pest and insects in agricultural crops. Reports suggest that IMI has highly toxic consequences on bees, humans and non-targeted aquatic animals. Hence the present study aims to investigate the toxicity effects of commercial-grade Imidacloprid (IMI) (Premise, 30.5\%, a.i) using histological and transcriptional changes in heat shock protein 70 (HSP70) and cytochrome P4501A(CYP1A) genes in liver and gills of nontargeted aquatic animal, Cyprinus carpio.

Methods: Three different sublethal concentrations of IMI (T1=26.04 mg/L, T2= $20.38 \mathrm{mg} / \mathrm{L}, \mathrm{T} 3=17.36 \mathrm{mg} / \mathrm{L})$ were selected and common carp fingerlings were exposed for 28 days where histological alterations and expression study of HSP70 and CYP1A in gills and liver of exposed fishes being studied on 7, 14, 21 and 28 days interval using standard procedure.

Result: Marked histological alteration like hydropic degeneration and cellular infiltration in liver; telangiectasis in secondary lamellae, epithelial lifting and oedema in gills were recorded. Moreover, significant upregulation of HSP70 and CYP1A gene in the gills and liver in a dose and time dependent manner was observed $(\mathrm{P}<0.05)$. As a result of the current investigation, it is obvious that IMI could be a possible toxicant that affects fish at the tissue and gene level in dosage and time dependent ways, potentially influencing other physiological processes in the long term.
\end{abstract}

Key words: CYP1A, Cyprinus carpio, HSP70, Imidacloprid, Sublethal.

\section{INTRODUCTION}

A neonicotinoid insecticide, imidacloprid (IMI) is used all over the world to control sucking pests like aphids, plant hoppers, whiteflies, and leafhoppers on crops (Ozdemir et al., 2018). IMI is an agonist of post-synaptic nicotinic acetylcholine receptors that binds to activates nicotine that causes impairments in the central nervous system. Moreover, excessive formation of reactive oxygen species (ROS) is also caused by high levels of Imidacloprid toxicity, resulting in oxidative stress (Ge et al., 2015). Since the European Food Safety Authority confirmed its harmful effects on bees and farmers, the usage of IMI has been a contentious subject. IMI was chosen because of its widespread usage, lack of linkage to aquatic toxicity in the region, or emerging use with past monitoring. After application, it can spread due to storms, agricultural run-off and spray drift into the aquatic environment. As a result, the possible negative effects of IMI exposure in non-target creatures, such as humans, animals, and especially aquatic animals, are gaining attention (Ozdemir et al., 2018).

HSPs are evolutionary conserved molecular chaperones that, among other things, transport, fold, and assemble faulty or misfolded proteins. The HSP70 (70-kDa) family of stress proteins is the most common and wellstudied. It has been shown to be activated in vitro and in vivo in response to a variety of environmental stresses,
College of Fisheries, Assam Agricultural University, Raha, Nagaon782 103, Assam, India.

Corresponding Author: Hemanta Pokhrel, Department of Aquatic Environment Management, College of Fisheries, Assam Agricultural University, Nagaon-782 103, Assam, India.

Email: hemanta.pokhrel.fd18@aau.ac.in

How to cite this article: Pokhrel, H., Sarmah, R., Bhagabati, S.K., Dutta, R., Ahmed, A.M., Nath, D., Mudoi, L., Ingtipi, L., Patowary, A.N. and Kalita, B. (2021). Effects of Imidacloprid on Histology and mRNA Levels of HSP70 and CYP1A Gene to a Standard Nontargeted Test Animal, Cyprinus carpio. Indian Journal of Animal Research. DOI: 10.18805/IJAR.B-4706.

Submitted: 06-07-2021 Accepted: 18-10-2021 Online: 29-10-2021

including oxidative stress (Clayton et al., 2005). Several isozymes of a CYP450 family in fish are also highly inducible by various toxic substances, play a significant role in xenobiotic metabolism. As a result, over the last decade, a growing number of researches have looked into the idea of employing CYP450 enzymes and HSPs as biomarkers of cellular deleterious effects. The stimulation and subsequent accumulation of CYP450 enzymes and HSPs are linked to the production of reactive oxygen species (ROS), as a result of which they can be employed as oxidative stress biomarkers (Li et al., 2015). Histopathological alterations 
caused by environmental pollutant or toxicant could also be due to oxidative stress which damages cytoplasm and nuclear membrane causing necrosis of the cell (Gunal et al., 2020).

Although there have been some studies on the acute toxicological effects of imidacloprid on aquatic organisms, but still there are information gaps in the long term sublethal toxicity effects of IMI on non-target aquatic animals, calling for more research in risk assessment. Thus, the aim of current study was to look into the long-term sublethal toxicity effects of commercially available IMI, Premise, 30.5\% a.i. on histology and gene expression (HSP70 and CYP1A) in the liver and gills of common carp Cyprinus carpio, a standard non-target test animal.

\section{MATERIALS AND METHODS} Ethical concern

Experiment was carried in Department of Aquatic Environment Management (AEM), College of Fisheries, Assam Agricultural University, Raha, Nagaon, during the year 2019-20. Care and treatment of obtained fish species were undertaken prior to the experiment in accordance with the Institutional Animal Ethics Committee of the College of Fisheries, Assam Agricultural University. The experimental protocol and endpoints were carried out in accordance with the committee's recommendations.

\section{Test chemical}

Imidacloprid (Premise 30.5\% a.i, 305 g/L), N-1-[(6-Chloro3-pyridyl) methyl]-4,5-dihydroimidazol-2-y I nitramide, was purchased from a local pesticide shop in Assam available under the trade name Premise, systematic insecticide registered and manufactured by Bayer Crop Science Limited, Thane West, India. To prepare the stock solution, the test chemical was measured using a micropipette. The working concentration was prepared freshly prior to use in the experiment.

\section{Collection and maintenance of animals}

The common carp fingerlings $(n=500)$, Cyprinus carpio (mean weight, $0.735 \pm 0.23 \mathrm{gm}$; mean length, $4.15 \pm 0.4 \mathrm{~cm}$ ) were obtained from the College of Fisheries, Assam Agricultural University, Raha, Nagaon scientific fish farm. The fishes were acclimatized to laboratory conditions for 21 days in a large cement cistern (1000 L capacity) containing dechlorinated water before exposure. The tank was provided with continuous aeration and a 12:12 h light-dark cycle was maintained throughout the experiment period. During the acclimatisation period, the fish were given commercial fish pellets containing $30 \%$ protein ad libitum twice daily. The physico-chemical parameters of the water used in the toxicity tests was as per OECD, (2019) guidelines.

\section{Toxicity test}

During the experiment, $96 \mathrm{hr} \mathrm{LC}_{50}$ concentration of Imidacloprid was found to be $208.38 \mathrm{mg} / \mathrm{L}$ (173.66 mg/L $262.37 \mathrm{mg} / \mathrm{L})(95 \% \mathrm{Cl})$. Based on this, three different sublethal concentrations $1 / 896 \mathrm{hr} \mathrm{LC}_{50}$ (T1=26.04 mg/L), 1/ 10 96hr LC 50 (T2=20.38 mg/L) and 1/12 96hr LC L $_{50}(\mathrm{~T} 3=17.36$ $\mathrm{mg} / \mathrm{L})$ were chosen to evaluate the sublethal toxicity effect on histology and genes expression (HSP70 and CYP1A) of gills and liver for 28 days. The incorporation of IMI in different treatments was done following Tisler et al. (2009). Fish were divided into four main groups, each with 60 individuals per aquaria of size $100 \mathrm{~L}(150 \times 60 \times 80 \mathrm{~cm})$ containing 80 Litres of test solution in a static renewal test chamber (EPA, 1996). In the control group fish were maintained with pesticide-free fresh water. Test medium was renewed every day to avoid dilution owing to active ingredient degradation (Lavanya et al., 2011). The experimental aquaria were aerated and fishes were hand-fed daily with formulated diet containing $30 \%$ crude protein up to apparent satiation of the fish. Control and each treatment were run in triplicate. Zero mortality with no apparent external alterations in morphology was recorded during the experimental period. At every $7^{\text {th }}, 14^{\text {th }}, 21^{\text {st }}$ and $28^{\text {th }}$ day of the exposure period, fishes were sacrificed, liver and gills tissues were collected and used for downstream studies.

\section{Histopathology}

The collected liver and gill tissues of exposed and control fishes $(n=10)$ were preserved in Neutral buffered formalin for histological analysis (NBF). They were then processed for paraffin wax embedding, cut into $5 \mu \mathrm{m}$ thick section using semi-automatic microtome (Leica) and stained with haematoxylin and Eosin ( $\mathrm{H}$ and $\mathrm{E}$ ) exactly as described by Humason (1979). Slides were then mount with DPx and examined under a compound microscope 100x/400x, (Zeisis Pri-moster; Tuscen Cam, USB $2.0 \mathrm{H}$ series) for any histopathological changes.

Total RNA isolation and reverse transcription quantitative real-time PCR (RT-PCR)

For the assessment of mRNA expression of HSP70 and

Table 1: Details of the Immune gene used in the study period.

\begin{tabular}{|c|c|c|c|c|}
\hline Name of the Gene & Sequence & size & Reaction conditions & Reference \\
\hline \multirow{2}{*}{$\begin{array}{l}\text { Heat shock protein } \\
\text { (HSP70) }\end{array}$} & F-5' TGAGAACATCAACGAGCCCA-3' & \multirow[t]{2}{*}{$121 \mathrm{bp}$} & $95^{\circ} \mathrm{C} 30 \mathrm{~s} / 95^{\circ} \mathrm{C} 15 \mathrm{~s} / 60^{\circ} \mathrm{C} 30 \mathrm{~s}$ & \multirow[t]{2}{*}{ Xing et al., 2012} \\
\hline & R-5'TTGTCAAAGTCCTCCCCACC-3' & & (40 cycles) & \\
\hline \multirow{2}{*}{$\begin{array}{l}\text { Cytochrome P450 } \\
\text { (CYP1A) }\end{array}$} & F5'АTTTCATTCCСAAAGACACСТG-3' & \multirow[t]{2}{*}{$159 \mathrm{bp}$} & $95^{\circ} \mathrm{C} 30 \mathrm{~s} / 95^{\circ} \mathrm{C} 15 \mathrm{~s} / 60^{\circ} \mathrm{C} 30 \mathrm{~s}$ & \multirow[t]{2}{*}{ Ozdemer et al., 2018.} \\
\hline & R-5'CAAAAACCAACACCTTCTCTCC-3' & & (40 cycles) & \\
\hline \multirow{2}{*}{$\begin{array}{l}\text { Beta actin } \\
\text { ( } \boldsymbol{\beta} \text {-actin) }\end{array}$} & F5'GATGGACTCTGGTGATGGTGTGAC-3' & \multirow[t]{2}{*}{$167 \mathrm{bp}$} & $95^{\circ} \mathrm{C} 30 \mathrm{~s} / 95^{\circ} \mathrm{C} 15 \mathrm{~s} / 60^{\circ} \mathrm{C} 30 \mathrm{~s}$ & \multirow[t]{2}{*}{ Xing et al., 2012} \\
\hline & R-5'TTTCTCTTTCGGCTGTGGTGGTG-3' & & (40 cycles) & \\
\hline
\end{tabular}


CYP1A, real time PCR was used with Real time PCR detection system (Hi-media). Total RNA from gill and liver of fish was isolated using TRIzol method following manufactures instruction (Hi-media MB601). The RNA samples were then treated with RNase and DNase free water (Hi-media ML024) and then cDNA synthesis was performed using a cDNA synthesis kit (Hi-cDNA synthesis Kit MB T076). 1 $1 \mu \mathrm{gos}$ each CDNA was used as a template for amplification using SBYR green master mix and gene specific primers. Primer sequence and the corresponding PCR conditions are listed in Table (1). $\beta$ - actin gene was used as the RT-qPCR internal control. Each PCR reaction was performed in triplicate. The specificity of PCR was confirmed by agarose gel electrophoresis and melting curve analysis. The results (fold changes) were determined following the method Xing et al. (2012).

\section{Statistical analysis}

Each treatment was conducted in triplicate. The means and standard errors were considered in the calculation. One-way ANOVA, followed by Duncan Post hoc test $(p<0.05)$ were conducted to evaluate the significant effects of data among treatment. Graphs were curated in GraphPad Prism v7.

\section{RESULTS AND DISCUSSION}

The findings of the current study suggest that exposure of carp fingerlings to three different sublethal concentrations of imidacloprid for 28 days showed low to moderate histological alterations and significant upregulation in (HSP70 and CYP1A) gene expression of liver and gills.

\section{Histological analysis}

The general histological examination revealed low to moderate damage in gill and liver tissues of common carp after exposure to three different sublethal concentration of IMI (T1=26.04 mg/L, T2= $20.38 \mathrm{mg} / \mathrm{L}, \mathrm{T} 3=17.36 \mathrm{mg} / \mathrm{L})$ or 28 days. Tissues obtained from the control groups showed normal features (Fig 1A and 2A). Hydropic degeneration (fig 1B) and cellular infiltration (Fig 1C) in liver as well as telangiectasis in secondary lamellae (Fig 2B), epithelial lifting and oedema (Fig 2C) in gills were observed in the evaluation of samples exposed to IMI.

Histological examinations have been proven to be very sensitive tool to evaluate the effects of toxicants on the exposed fish tissues (Dawood et al., 2020). Fish liver is regarded as the main organ of several metabolic pathways and changes in the liver histology is being widely used as biomarkers of toxicant and carcinogen exposure damage (Khafaga et al., 2020). Hepatic degeneration withing hepatocytes and hepatopancreatic cells was a common phenomenon to toxicant exposure. Ozdemir et al. (2018) noticed hydropic degeneration in hepatocytes and necrosis in liver tissues, mononuclear cell infiltration that induced inflammation of liver and passive hyperaemia and disruption of hepatic tissue organisation when exposed to various concentration of IMI for $96 \mathrm{hr}$.

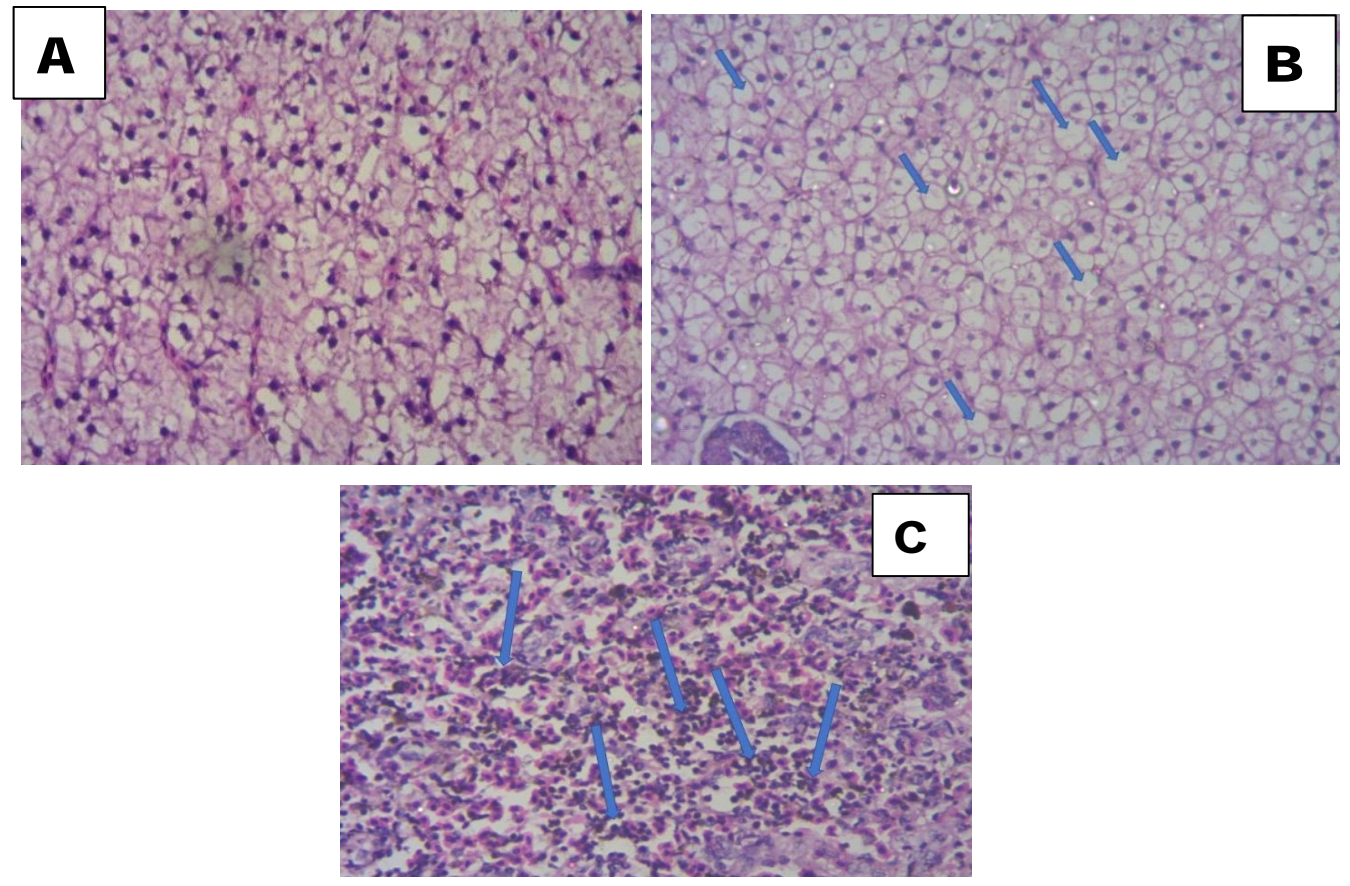

Fig 1: Representative photomicrographs of the liver tissues of common carp Cyprinus carpio (H \& E stain, 400x). A. Control (400x) Liver. B. Hydropic degeneration (arrow). C. Mononuclear cell infiltration that induced inflammation of liver and passive hyperaemia (arrow). 

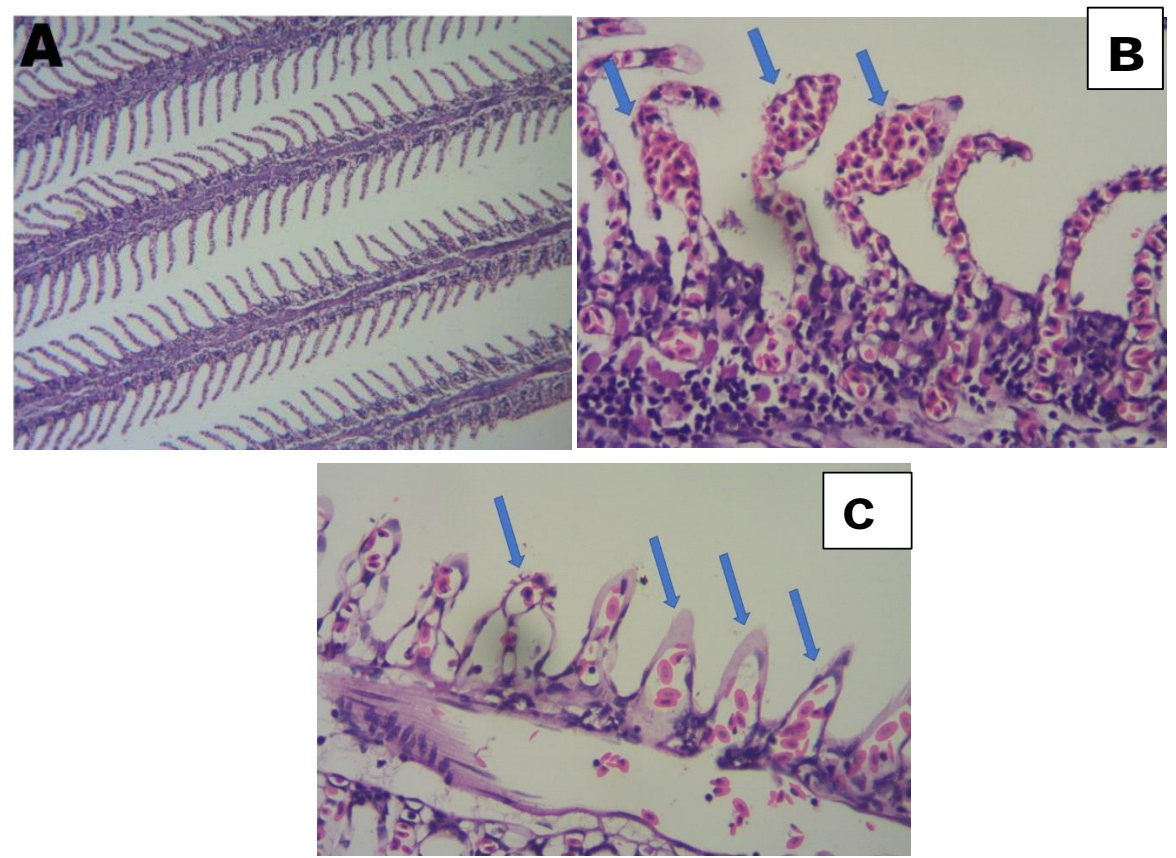

Fig 2: Representative photomicrographs of the Gill tissues of common carp Cyprinus carpio (H \& E stain, 400x). A. Control (100x) Gill. B. Telangiectasia in the secondary lamellae (arrow). C. Epithelial lifting and oedema of secondary lamellae (arrow).

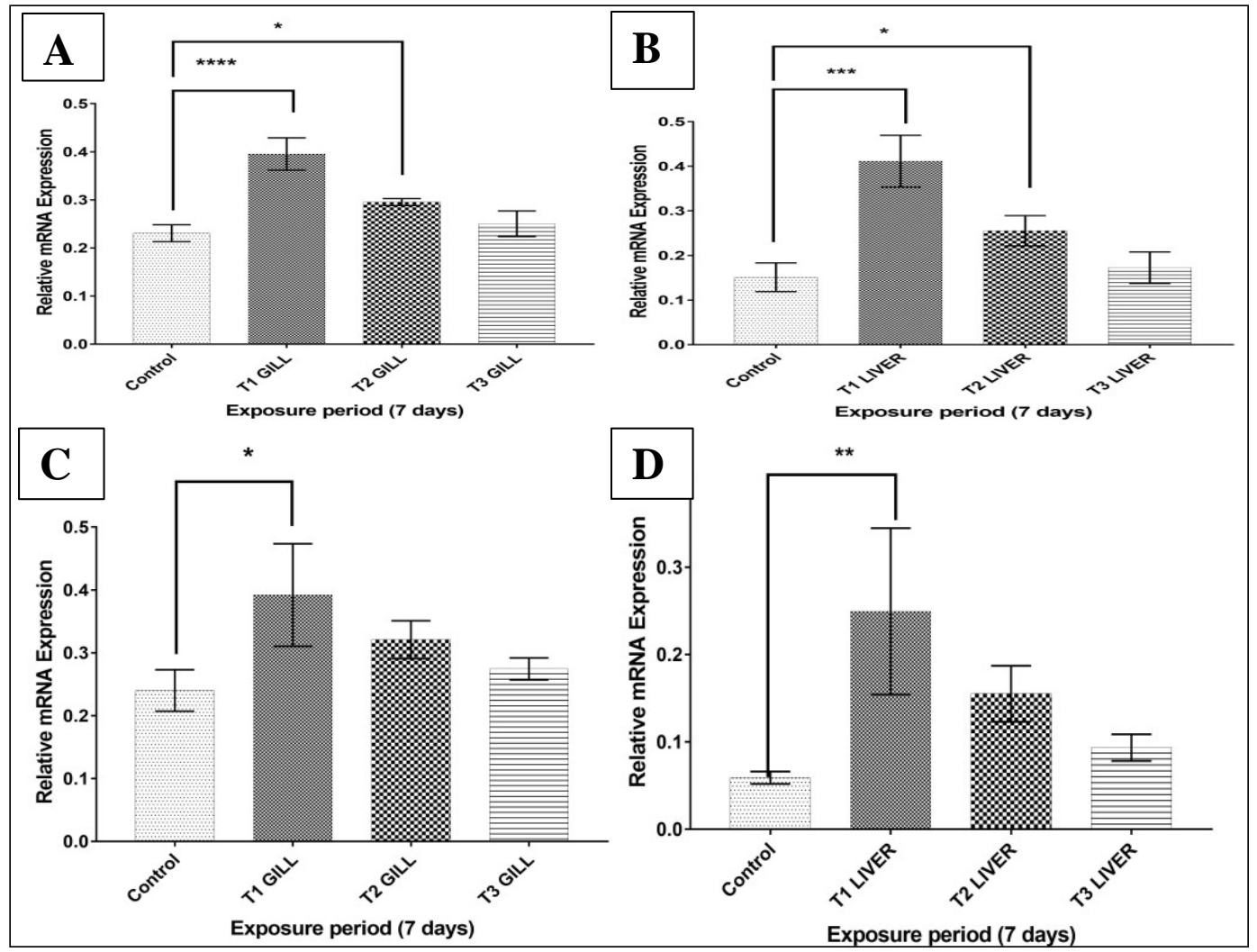

Fig 3: Effect of $T_{1}(26.04 \mathrm{mg} / \mathrm{L}), T_{2}(20.38 \mathrm{mg} / \mathrm{L})$ and $T_{3}(17.36 \mathrm{mg} / \mathrm{L})$ doses of IMI exposure for $7^{\text {th }}$ day on mRNA transcript levels of HSP70 and CYPIA in the Gills and Liver of common carp. Values represent the mean \pm SE; $n=3$; error bars indicate standard deviation. Statistical significance represents $\left({ }^{*} \mathrm{p}<0.05,{ }^{* *} \mathrm{p}<0.01,{ }^{* * *} \mathrm{p}<0.001,{ }^{* * * *} \mathrm{p}<0.0001\right)$ was analysed under one-way ANOVA using Graph pad prism version 7.0. A. Represents the relative mRNA expression levels of HSP70 of gills. B. Represents the relative mRNA expression levels of HSP70 of liver. C. Represents the relative mRNA expression levels of CYPIA of gills. D. Represents the relative mRNA expression levels of CYPIA of liver. 
Owing to susceptible nature, fish gill tissues are often considered as water quality monitors and bioindicators of toxicant exposure (Erkmen et al., 2017). The hyperplasic alterations are nonspecific defence responses delineated to protect the organism due to increasing uptake of many xenobiotics by augmenting distance between the chemical and the blood vessels (Gunal et al., 2020). Similar kind of observations like epithelial lifting, proliferation and fusion of the secondary lamella on Oreochromis mossambicus was observed by Ozdemir et al. (2018).

\section{Gene expression studies}

The results were analysed and the fold changes in the expression of the gene (HSP70 and CYP1A) in gill and liver samples are shown in Fig (3, 4, 5 and 6$)$. The mRNA level of HSP70 in gill was significantly upregulated in treatment
T1 and T2 on day 7, 14, 21 and 28 (Fig 3A, 4A, 5A and 6A), whereas HSP70 in the liver was significantly upregulated in all the treatments $\mathrm{T} 1, \mathrm{~T} 2$ and $\mathrm{T} 3$ on day $7,14,21$ and 28 except T3 on day 7 (3B, 4B, 5B and $6 B)(p<0.0001)$. Similarly, CYP1A gene in gill and liver was significantly upregulated in treatment $\mathrm{T} 1$ and $\mathrm{T} 2$ on days 7, 14, 21 and 28 (Fig 3C, 4C, $5 \mathrm{C}$ and $6 \mathrm{C}$ ) and $\mathrm{T} 1$ on day $7, \mathrm{~T} 1$ and $\mathrm{T} 2$ on day 14 and 21 , and T1, T2 and T3 on day 28 (Fig 3D, 4D, 5D and 6D) respectively $(p<0.05)$.

The physiological response of a fish to external stimuli typically includes HSP70 expression. Numerous studies have revealed that environmental stressors such as metal pollution and toxic chemicals have significant influence on fish HSP70 (Dang et al., 2010). In the present study, significant increase in the expression of the HSP70 gene was observed between three different sub-lethal

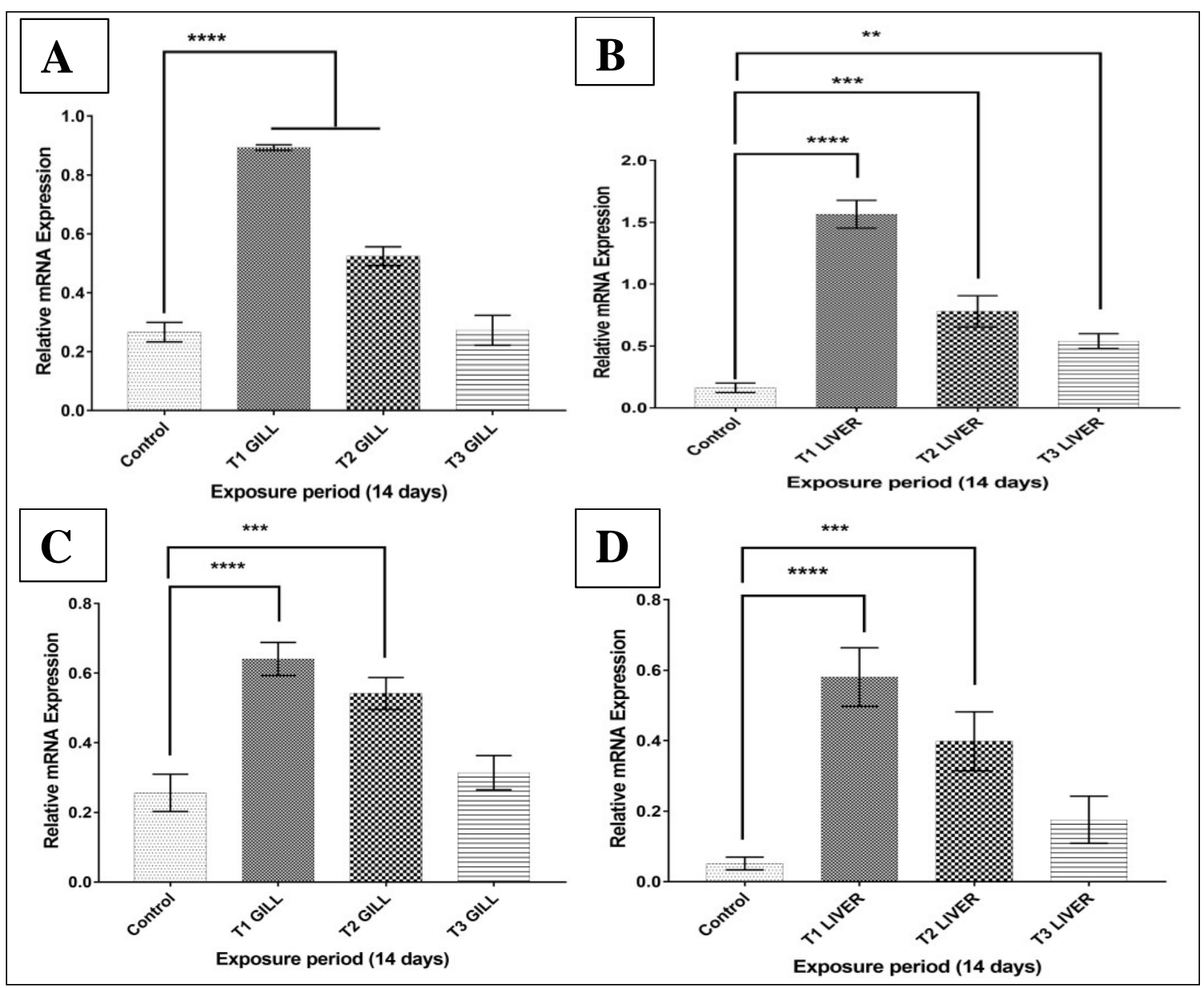

Fig 4: Effect of $T_{1}(26.04 \mathrm{mg} / \mathrm{L}), \mathrm{T}_{2}(20.38 \mathrm{mg} / \mathrm{L})$ and $\mathrm{T}_{3}(17.36 \mathrm{mg} / \mathrm{L})$ doses of IMl exposure for $14^{\text {th }}$ day on mRNA transcript levels of HSP70 and CYPIA in the Gills and Liver of common carp. Values represent the mean \pm SE; $n=3$; error bars indicate standard deviation. Statistical significance represents $\left({ }^{*} p<0.05,{ }^{* *} p<0.01,{ }^{* * *} p<0.001,{ }^{* * *} p<0.0001\right)$ was analysed under one-way ANOVA using Graph pad prism version 7.0. A. Represents the relative mRNA expression levels of HSP70 of gills. B. Represents the relative mRNA expression levels of HSP70 of liver. C. Represents the relative mRNA expression levels of CYPIA of gills. D. Represents the relative mRNA expression levels of CYPIA of liver. 


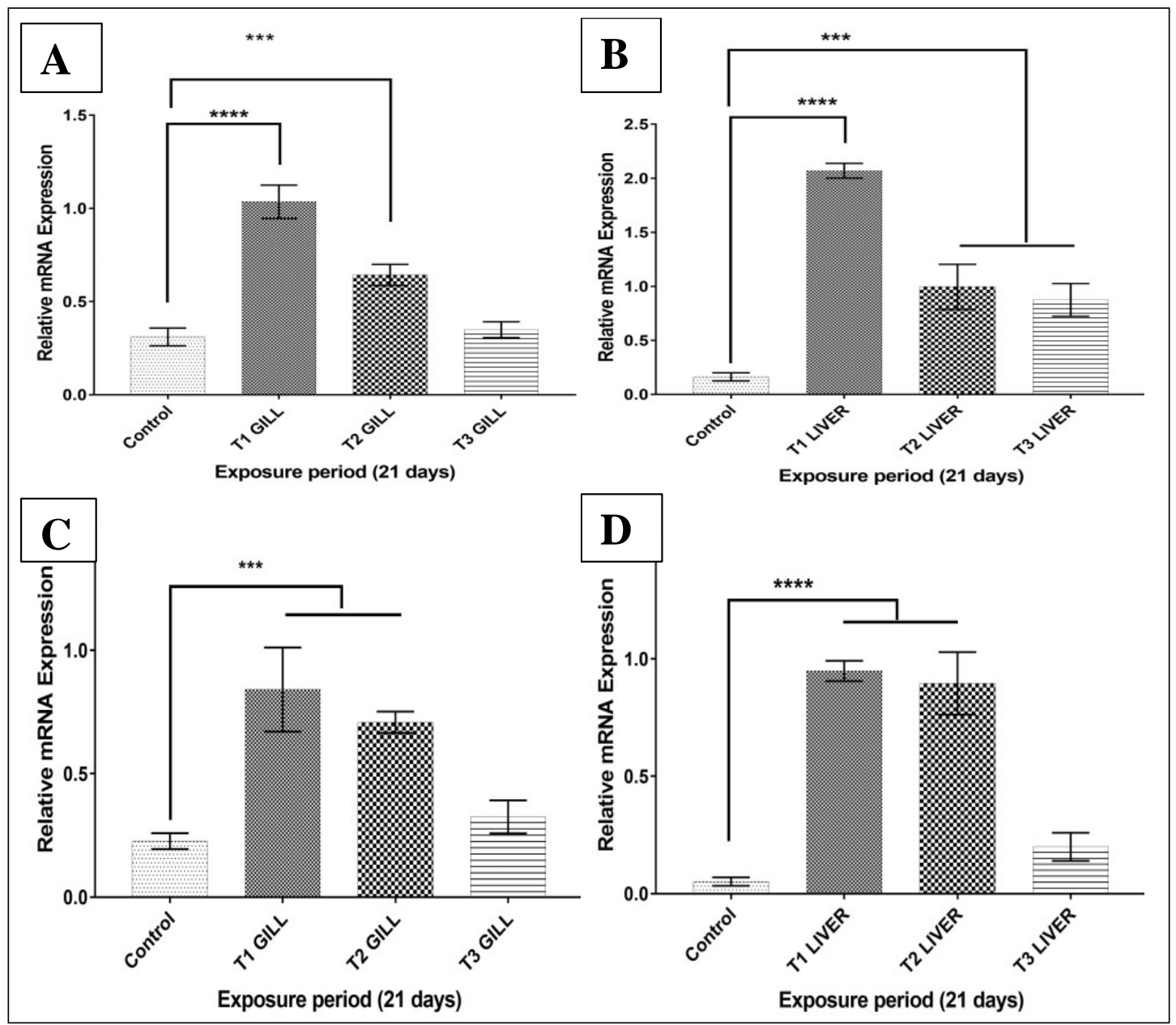

Fig 5: Effect of $\mathrm{T}_{1}(26.04 \mathrm{mg} / \mathrm{L}), \mathrm{T}_{2}(20.38 \mathrm{mg} / \mathrm{L})$ and $\mathrm{T}_{3}(17.36 \mathrm{mg} / \mathrm{L})$ doses of IMl exposure for $21^{\text {th }}$ day on mRNA transcript levels of HSP70 and CYPIA in the Gills and Liver of common carp. Values represent the mean \pm SE; $n=3$; error bars indicate standard deviation. Statistical significance represents $\left({ }^{*} p<0.05,{ }^{* *} p<0.01,{ }^{* * *} p<0.001,{ }^{* * * *} p<0.0001\right)$ was analysed under one-way ANOVA using Graph pad prism version 7.0. A. Represents the relative mRNA expression levels of HSP70 of gills. B. Represents the relative mRNA expression levels of HSP70 of liver. C. Represents the relative mRNA expression levels of CYPIA of gills. D. Represents the relative mRNA expression levels of CYPIA of liver.

concentrations of IMI in dose and time dependent manner. Similar kind of findings like increase in mRNA levels of HSP70 in brain, kidney and gill of common carp was reported by Xing et al. (2012) when exposed to different concentration of atrazine and chlorpyrifos. Pesticides may impair cells' ability to cope with oxidative stress, resulting in the production of free radicals or enzyme systems that scavenge free oxygen radicals. Oxidative stress can also cause earlystage HSP70 mRNA expression, implying that oxygen radicals, particularly superoxide anions, have a role in HSP70 expression (Kukreja et al., 1994).

CYP1A, a member of the cytochrome P450 (CYP) enzyme superfamily, is a key enzyme in drug and chemical metabolism in fish and other animals (Tsuchiya et al., 2005).
Thus, it may provide useful information about fish behaviour and health resulting from environmental stress (Uno et al., 2012). Higher levels of CYP1A mRNA in the liver in the treatment groups could be due to de novo synthesis rather than CYP1A mRNA stability or degradation rates. CYP1A gene was significantly upregulated in both gills and liver during the experimental period which might be due to increase in ROS production cause by IMI toxicity (Narr, 2014). Similar, kind of findings like increases in CYP1A mRNA level upon sublethal exposure to IMI was also reported by Ozdemir et al. (2018) in C. carpio. Li et al. (2015) also reported the upsurge expression of CYP1A mRNA in liver, gills, and muscle treated with biocide tributylin (TBT) in common carp. 


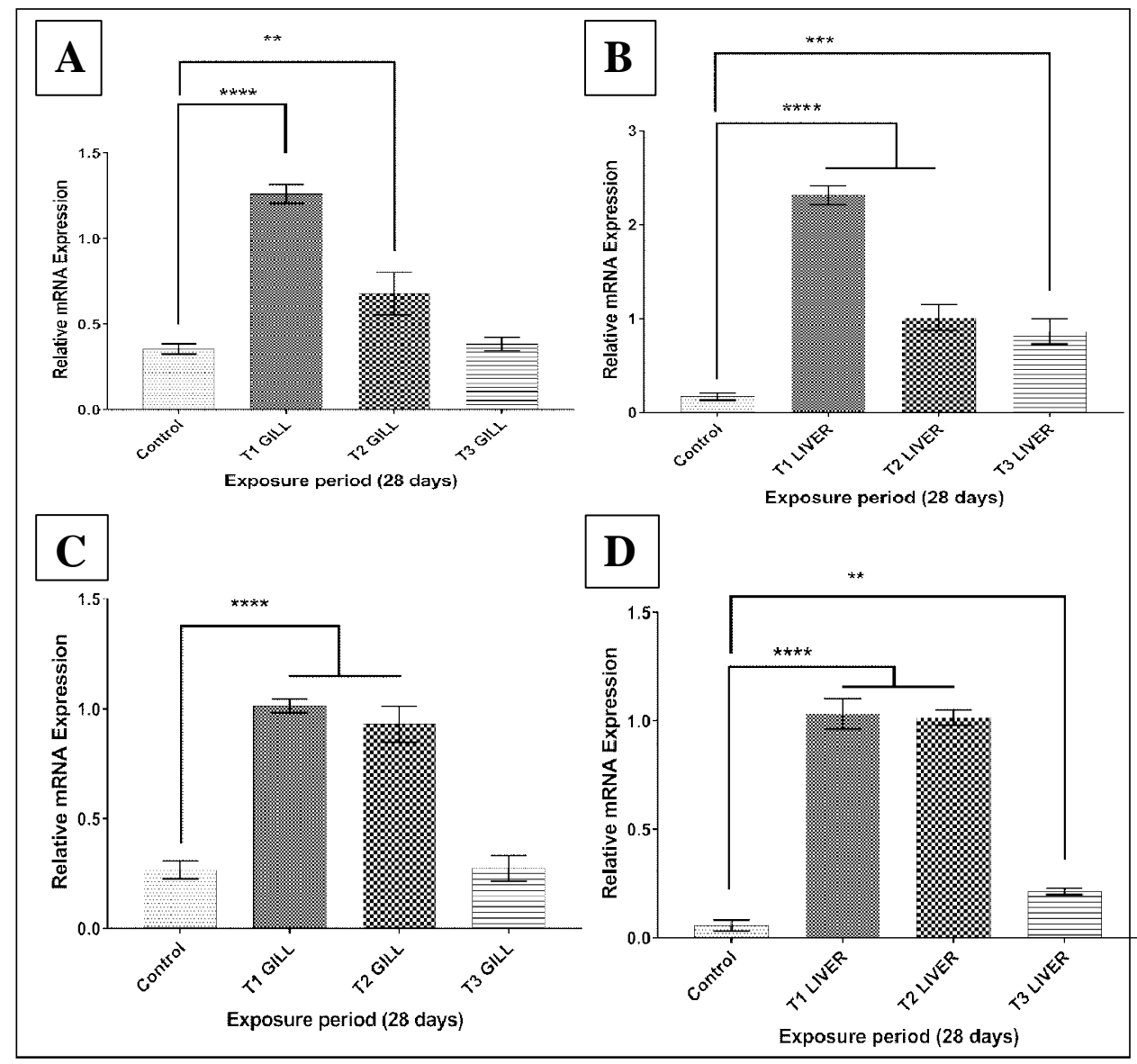

Fig 6: Effect of $T_{1}(26.04 \mathrm{mg} / \mathrm{L}), T_{2}(20.38 \mathrm{mg} / \mathrm{L})$ and $T_{3}(17.36 \mathrm{mg} / \mathrm{L})$ doses of IMl exposure for $28^{\text {th }}$ days on mRNA transcript levels of HSP70 and CYPIA in the Gills and Liver of common carp. Values represent the mean \pm SE; $n=3$; error bars indicate standard deviation. Statistical significance represents $\left({ }^{*} p<0.05,{ }^{* *} p<0.01,{ }^{* * *} p<0.001,{ }^{* * * *} p<0.0001\right)$ was analysed under one-way ANOVA using Graph pad prism version 7.0. A. Represents the relative mRNA expression levels of HSP70 of gills. B. Represents the relative mRNA expression levels of HSP70 of liver. C. Represents the relative mRNA expression levels of CYPIA of gills. D. Represents the relative mRNA expression levels of CYPIA of liver.

\section{CONCLUSION}

The present study confirmed that Imidacloprid (Premise, $30.5 \%$ a.i) induces low to moderate histological alterations like telangiectasis in secondary lamellae, epithelial lifting and edema in gills; hydropic degeneration and cellular infiltration in the liver and significant upregulation of HSP70 and CYP1A gene in gill and liver. The alterations of these parameters in $C$. carpio represented a sensitive and effective tool for reflecting the toxicity of pollutants in aquatic environment. The findings reveals that imidacloprid is a very hazardous chemical in aquatic life, capable of affecting cellular function even at sub-lethal concentrations.

\section{ACKNOWLEDGEMENT}

This study was carried out as a part of the "Himalayan Research Fellowship Programme" (Grant ID: GBPNI/NMHS/ 2017-18/HSF-04/600). The authors are highly grateful to National Mission on Himalayan Studies (NMHS), MOEFCC,
Govt. of India and Nodal Institute GBPNIHESD for the financial assistance. Dean, College of Fisheries Assam Agricultural University, Raha, Nagaon is also duly acknowledged for his kind support and guidance.

\section{REFERENCE}

Clayton, A., Turkes, A., Navabi, H., Mason, M.D., Tabi, Z. (2005). Induction of heat shock proteins in B-cell exosomes. Journal of Cell Science. 118(16): 3631-3638.

Dang, W., Hu, Y.H., Zhang, M., Sun, L.I. (2010). Identification and molecular analysis of a stress-inducible Hsp70 from Sciaenops ocellatus. Fish and shellfish immunology. 29(4): 600-607.

Dawood, M.A., Moustafa, E.M., Gewaily, M.S., Abdo, S.E., AbdEIKader, M.F., Saad Allah, M.S., Hamouda, A.H. (2020). Ameliorative effects of Lactobacillus plantarum L-137 on Nile tilapia (Oreochromis niloticus) exposed to deltamethrin toxicity in rearing water. Aquatic Toxicology. 219: 105377. 
Erkmen, B., Karasu Benli, A.Ç., Aðup, H.H., Yıldırım, Z., Mert, R., Erkoç, F. (2017). Impact of sublethal di $n$ butyl phthalate on the aquaculture fish species Nile tilapia (Oreochromis niloticus): histopathology and oxidative stress assessment. Aquaculture Research. 48(2): 675685.

EPA (1996). Ecological Effect Test Guidelines. Fish Acute Toxicity Test, Freshwater and Marine (7101), OPPTS 850.1075.

Ge, W., Yan, S., Wang, J., Zhu, L., Chen, A., Wang, J. (2015). Oxidative stress and DNA damage induced byimidacloprid in zebrafish (Danio rerio). Journal of Agricultural and Food Chemistry. 63(6): 1856-1862.

Günal, A.Ç., Erkmen, B., Paçal, E., Arslan, P., Yildirim, Z., Erkoç, F. (2020). Sub-lethal Effects of IMI on Nile Tilapia (Oreochromis niloticus). Water, Air and Soil Pollution. 231(1): 1-10.

Humason, G.L. (1979). Animal tissue techniques, $4^{\text {th }}$ ed. W.H.Freeman and Co., San Francisco, California, 661.

Khafaga, A.F., Naiel, M.A., Dawood, M.A., Abdel-Latif, H.M. (2020). Dietary Origanum vulgare essential oil attenuates cypermethrin-induced biochemical changes, oxidative stress, histopathological alterations, apoptosis and reduces DNA damage in Common carp (Cyprinus carpio). Aquatic Toxicology: 228: 105624.

Kukreja, R.C., Kontos, M.C., Loesser, K.E., Batra, S.K., Qian, Y.Z., Gbur Jr, C.J., Naseem, S.A., Jesse, R.L., Hess, M.L. (1994). Oxidant stress increases heat shock protein 70 mRNA in isolated perfused rat heart. American Journal of Physiology-Heart and Circulatory Physiology. 267(6): 2213-2219.
Lavanya, S., Ramesh, M., Kavitha, C., Malarvizhi, A. (2011). Hematological, biochemical and ionoregulatory responses of Indian major carp Catla catla during chronic sublethal exposure to inorganic arsenic. Chemosphere. 82(7): 977-985.

Li, L., Tan, J., Miao, Y., Lei, P., Zhang, Q. (2015). ROS and autophagy: Interactions and molecular regulatory mechanisms. Cellular and Molecular Neurobiology. 35(5): 615-621.

Narr, M.R. (2014). Tissue-Specific recovery of oxidative and antioxidant effects of chlorpyrifos in the freshwater crab, Barytelphusa guerini. Archives of Environmental Contamination and Toxicology. 67: 158-166.

OECD. (2019). Guidance Document on Aquatic Toxicity Testing of Difficult Test Chemicals and Mixtures. Series on Testing and Assessment No. 23, OECD, Paris.

Ozdemir, S., Altun, S., Arslan, H. (2018). IMI exposure cause the histopathological changes, activation of TNF-a iNOS, 8-OHdG biomarkers and alteration of caspase 3, iNOS, CYP1A, MT1 gene expression levels in common carp (Cyprinus carpio L.). Toxicology reports. 5: 125-133.

Tišler, T., Jemec, A., Mozetiè, B., Trebše, P. (2009). Hazard identification of IMI to aquatic environment. Chemosphere. 76(7): 907-914.

Tsuchiya, Y., Nakajima, M., Yokoi, T. (2005). Cytochrome P450mediated metabolism of estrogens and its regulation in human. Cancer Letters. 227: 115-124.

Uno, T., Ishizuka, M., Itakura, T. (2012). Cytochrome P450 (CYP) in fish. Environmental Toxicology and Pharmacology. 34(1): 1-13.

Xing, H., Wang, X., Sun, G., Gao, X., Xu, S., Wang, X. (2012). Effects of atrazine and chlorpyrifos on activity and transcription of glutathione S-transferase in common carp (Cyprinus carpio L.). Environmental Toxicology and Pharmacology. 33(2): 233-244. 